\title{
POLITENESS, SPEECH ACT, AND DISCOURE IN SASAK COMMUNITY
}

\section{(SOPAN SANTUN, TINDAK TUTUR, DAN WACANA DALAM KOMUNITAS SASAK)}

\author{
Muh. Junaidi \\ Universitas Islam Negeri Mataram \\ Pos-el: muhjunaidi13@gmail.com
}

Diterima: Februari 2017; Direvisi: 17 Oktober 2017; Disetujui: 23 Oktober 2017

\begin{abstract}
Politeness, speech act and discourse have become an interest area of language use in context. Attention has been drawn to the universality of politeness strategies across the culture. This study examines the nature of pattern of communication in terms of politeness, speech acts and discourse in Sasak speech community. The subject of the study is 1 Tuan Guru giving religious speech in Sikur village. Participant observation is used as the method of data collection in this study. A video recording was used to collect data. Result of the study shows that reminding and suggesting are not the acts of indicating or threatening addressees' negative face, but positive strategies used to minimize the threat for addressees' positive face and negative one as a means of saving addressees' negative face. These three variables were interrelated to decipher the nature of speech pattern of language use in the Sasak speech community. The notion of face should be analyzed according to norms and cultural values of such acts in different speech communities. Hence, the universality of communicative action and the type of speech act in a given speech community are crucial variable to scrutinize the language use in context.
\end{abstract}

Keywords: politeness, face, speech act, discourse

\begin{abstract}
Abstrak
Sopan santun, tindak tutur, dan wacana telah menjadi sutu bidang kajian yang menarik dalam penggunaan bahasa dalam konteks. Banyak perhatian tertuju pada keuniversalan strategi sopan santun antarbudaya. Penelitian ini mengkaji pola komunikasi dalam kaitannya dengan Sopan santun, tindak tutur, dan wacana di komunitas tutur Sasak. Subjek dalam kajian ini adalah seorang tuan guru yang memberikan ceramah di desa Sikur. Metode pengumpulan data yang digunakan adalah observasi partisipan. Untuk mengumpulkan data digunakan rekaman video. Hasilnya, mengingatkan dan menyarankan adalah bukan tindakan yang mengancam negatif face audiens, namun tindakan berbahasa tersebut merupakan strategi positif digunakan untuk mengurangi ancaman terhadap positif face pendengar dan strategi negatif digunakan untuk menjaga negatif face pendengar. Ketiga variabel tersebut saling berkaitan dalam memahami pola tuturan dalam penggunaan bahasa dalam komunitas tutur Sasak. Istilah face harus dianalisis berdasarkan norma dan nilai budaya dari tindakan-tindakan berbahasa dalam komunitas tutur yang berbeda sehingga keuniversalan dari tindakan komunikasi dan tipe tindak tutur dalam suatu komunitas tutur tertentu adalah variabel yang penting dalam mengurai penggunaan bahasa dalam konteks.
\end{abstract}

Kata kunci: sopan santun, tindak tutur, dan wacana 


\section{Introduction}

Speech behavior varies across culture and community. The empirical phenomena of such pattern of communication have intertwined with the culture. Such manifestation shared by a speech community does not only signal the varieties of linguistic features, but also represent particular norms and values. In this respect, language is symbolic and has an interactive function. Leading thinkers, philosophers, and linguists long has been trying to understand how language is used. The main concern for philosophers and linguists is the same: setting out to find the truth of reality. In fact, the diversity of language use involves linguistic and extralinguistic factors. It indicates different perspectives on the relationship of language with human mental states, culture, religion, ethnicity and so forth. Regarding language use, linguistic features are established by language users, reflecting their linguistic and communicative competence. The former is relative to the speakers' ability of language grammars, such as, syntax, phonology, morphology and semantics. However, not having such abilities does not mean that the speakers will not be able to use the language appropriately. The latter means that speakers should know how to use language, when to choose a particular feature, and with whom they are expected to use such features. Specifically, they must have communicative competence in order to use the language in an appropriate manner. By having both competences, they may achieve their goals in language use.

Sasak people speak tow other languages including Indonesian and Sasak language along with five dialects of the Sasak language. Given such a fact, speech behaviour and norms such as politeness, speech acts are observable. Sasak language is primarily spoken in the island of Lombok, West Nusa Tenggara, Indonesia, near the east of Bali. There is a great deal of linguistic features within Sasak language. Traditionally, Sasak language has five dialects:

a. Ngeno-Ngene, in Central West coast and Central East to North East coast,

b. Meno-Mene, around of Puyung and Praya, in Central Lombok,

c. Ngeto-Ngete, around Suralaga and Sembalun in the North East.

d. Ngeno-Meni, around Bayan in the North (also called kuto-kute),

e. Meriaq-Meriku, South central area around Bonjeruk and Sengkol (Pujut).

In accordance with these varieties, the occurrence of language use in Sasak community may be not only influenced by linguistic factors, but also affected by the culture, norms and values. Besides, the type of acts has a relationship with politeness, and social factors that influence the speaker to use a particular act. Dealing with speech 
acts, Tuan Guru, a religious person having deep understanding about Islam, is an elite class in the Sasak community and a person who is admitted by the Sasak people based on his ability in Islamic studies. There is a need for conducting this study on politeness, speech acts and discourse in the Tuan Guru speech.

In addition to the circumstance, scrutinizing the deviation in terms of linguistic diversity across the culture also needs to be examined and advocate previous theories on politeness and discourse. The dispute on the universality of Brown and Levinson's face theory require profound examination and study whether it is applicable in Sasak community. In fact, there is cultural diversity influencing language use, especially a number of acts used by the speech community. In other words, the context of language use is not only situational and co-textual, but also background interrelated with culturally bound context. Thus, it is important to examine the application of politeness theory i.e. face and to correlate it with the framework of discourse. Furthermore, the study examined the nature of tuan guru speech grounded on the type of ILS and communicative action.

\section{Theoretical framework}

The term of face was first introduced by Goffman (1967) in his essays Interaction Rituals: Essays on Face-toFace behaviour. His emphasis on the concept of face was based on social interaction. To understand the face to face interaction, rules and normative understandings in a particular society these are pivotal aspects (Goffman, 1967). He proposed three basic interactions: first, social occasion: it deals with the setting and sets of the tones as to what happens in that specific event. Second, gathering: this regards with a number of individuals involved during the events. The third, social situation: it is relative to spatial circumstances where the participants become members of interactions. Goffman (1967) claimed that social face, personal possession and the centre of one's security and pleasures are only a loan from society. In this respect, it is the constraint of one's face which is governed and bounded by particular legalised and societal rules.

Goffman defines face as a public image described in terms of approved societal attributes (1967, p.5). The implication of social interaction in order to determine one's position and world knowledge, Goffman (1967) believes that face is the core element of social interaction. Thus maintaining or losing face is mutual responsibility. Although, face is 
an individual possession it is not absolute. In other words, it is dependent on the society in which it can be withdrawn when one's act deviate from the rules or norms legitimated in a given society. In this respect, Goffman's concept of face is situationally oriented, hence there is no absolute freedom for an individual to do whatever he wants, but it is under a bounded norm and is controlled by the society whether one's act preserve his face or not.

Doing an event or making interaction embody the individual's face that may be lost or maintained. Goffman (1967) suggested being poises could be one type of face-work. A full or part consequence of face saving action is understood by participants, since it becomes a habitual and standardised practice. By having the diversity of cultural bound concept of face-saving, Goffman revealed “...each person, sub-culture, and society seems to have own characteristic repertoire of face-saving practice" (p.13). Thus face saving varies across society and culture.

In accordance with face, Goffman (1967) differentiated three sorts of face: first, a good face, it is possessed when one effectively takes present in an image of him that is internally consistent, it is supported by judgment and evidence conveyed through impersonal agency in the situation.
The second, wrong face refers to when the information is brought forth in some way about his social worth which cannot be integrated, even with efforts, into the line that is being sustained for him. Third, we may say one is out of face when he participates in a contact with others without having ready a line of the kinds of participants in such situations are expected to take (p.8).

In addition, Goffman (1967) does not only define the concept of face, but also admitted the pivotal rule of saving-face self. He argued "the combined effect of the rule of self-respect and the rule of indirectness is that a person tends to conduct himself during encounter so as to maintaining both his own face and other's face" (Goffman, 1967, p.11). Furthermore, according to Goffman perspectives, saving face interaction involve two orientations: defensive and protective dimension. The former refers to one's action to save hisface, while the latter regards with one's action to save other's face.

Grice (1975) in his essays "logic and conversation" emphasized the role of mutual co-operation. It means that the participants, both the speaker and addressee, should co-operate each other in order to achieve their goal of communication. In this respect, Grice proposed the notion of cooperative principle governed by a set of general 
principles in which the addressee follows those principles when engaging in conversational interaction. Grice (1975) states:

"Our talk exchanges do not normally consists of succession of disconnected remarks, and would not be rational if they did. They are, characteristically, to some degree at least, cooperative principle . . . a common purposes or set of purposes. (p.45)"

Grice pioneered the term "implicature" and proposed the existence of meaning beyond the convectional meanings of the words. For effective communication, he theoritized the Cooperative Principles that consistof four maxims and a number of sub-maxims. Here are the maxims and submaxims proposed by Grice (1975, p. 45--46):

a. Maxim of quantity:

1) Make your contribution as informative as it is required (for the current purposes of the exchange).

2) Do not make your contribution more informative than it is required.

b. Maxim of quality

1) Do not say what you believe to be false.

2) Do not say for which you lack adequate evidence.

c. Maxim of relation

1) Be relevant

d. Maxim of manner

1) Avoid obscurity of expression.
2) Avoid ambiguity.

3) Be brief.

4) Be orderly

To sum up, Grice (1975) holds that quantity, quality, and relevant maxims and its sub-maxims are relative to what is said (content), while the last pertains to way to say what to say.

Lakoff's (1975) maximally projected on Grice's CP to determine rules for scrutinise diversity of politeness cases, either intercultural or across cultures. Grammatical rules and well-formedness were expanded to the areas of pragmatics. In accordance with an ill-formed sentence derived from syntactic and semantic angles, she postulated two rules forming the basis of pragmatic competence: 1) be clear and 2) be polite (Lakoff, 1973, p.303). She believed that the conflict between two rules due to the purposes of communication. The clarity will be focused if the interaction is to deliver straightforward information, on the other hand it will be polite if the main concern is to bear harmonious or dynamic relationship. The second rule, along with three sets of rules: a) do not imposes (distance), b) give options (deference), and c) make the audience feel good or be friendly.

In this respect, the sub-rules 'do not impose' is related to formal politeness in which the distance and formality are related to politeness. For less formal or informal 
interaction politeness 'give option', deference is significant properties of those of politeness. Finally, the last rule "be friendly" symbolises intimacy toward the hearer (Watts, 2003).

Leech (1983) attempts to formulate the general pragmatics. This principle proposed concern with the linguistic politeness phenomena contributing to general pragmatics. He also proposed two terms: pragmalinguistics and sociopragmatics. The former refers to particular resources which a given language providing for conveying particular illocution, while the latter concerned with the specific local condition of language use (p. 11).

In accordance with the general pragmatics, Leech (1983) formulated the rhetorical approach. He distinguished two types of them: first, textual rhetoric covers prossessibility, clarity, economy, and expressive principle. Second, interpersonal rhetoric consists of cooperative, politeness and irony principle (p.16).

The same way as Lakoff (1973), Leech (1983) expanded Grice's CP on : why some prefer to be indirect when conveying certain messages? He proposed some maxims and specific types of illocutionary act (Leech, 1983, p.132):

1) Tact maxim

a. Minimise cost to others.

b. Maximise benefit to others.
2) Generosity maxim
a. Minimise benefit to self.
b. Maximise cost to self.

3) Approbation maxim
a. Minimise dispraise of other.
b. Maximise praise of other

4) Modesty maxim
a. Minimise praise of self.
b. Maximise dispraise of self.

5) Agreement maxim

a. Minimise disagreement between self and others.

b. Maximise agreement between self and others.

6) Sympathy maxim

a. Minimise antipathy between self and other.

b. Maximise sympathy between self and other.

Leech's model proposed the costbenefit scale designating how participants's relationships are. In other words, in one hand, speakers or hearers have to minimise negative force, and on the other hand, participants have to maximise positive force on each other. In addition, Leech (1983) postulated the distinction of speech acts: impolite acts, such as, request and orders; and polite acts as in thanks and offers. In summary, he proposed negative politeness as an act of reducing impoliteness of impolite illocution and positive politeness as the act of increasing politeness of polite illocution. 
Brown and Levinson (1987) proposed the politeness model grounded over the notion of 'Face' suggested first from Goffman and the maxim model by Grice. Brown and Levinson (1987) define 'face is the public self-image that every member wants to claim for himself' (p.61). In other words, face relates to the consequence of acts for speakers (S) and addresses (A) self-esteems whether or not the kinds of acts trigger any threats for $\mathrm{S}$ and A. The face consists of two related elements: positive and negative face. The former refers to $\mathrm{S}$ or A's desire of their self-esteems being approved by the acts chosen. While the latter regards with 'the basic claim to territories, personal preserve, rights not to distraction-i.e. to freedom of action and freedom from imposition (ibid.). In accordance with negative face, the speakers or addresses want their actions, ideas, thoughts not to be blocked by others. Furthermore, the nature of the face notion emphases on intrinsic factors, i.e. S and A's want to engaged in discourse or a conversation rather than valuable norms in a particular community.

The theory of politeness was proposed by Brown and Levinson (1987) and was based on the assumption that a number of speech acts may naturally threat the speakers and addressees' face. The different speech acts chosen get rise to threatening for both $\mathrm{S}$ and $\mathrm{A}$, since they do not countenance $\mathrm{S}$ and $\mathrm{A}$ 's face in a particular discourse or conversation. Acts are the speakers' intentions hoping that their wants can be achieved through verbal and nonverbal communication. Brown and Levinson (1987, p.65--68) elaborated facethreatening acts (FTAs) in respects with the type of face threatened as well as whose face threatened. The acts of threatening $S$ negative face include expressing thanks, excuse, and acceptance of offers, unwilling promises and offers. While the acts threatened $S$ positive face involves apologies, acceptance of a compliment, self humiliation, confession of guilty and responsibility, emotion leakage. In addition, the acts threatening a negative face by $\mathrm{S}$ encompasses orders and requests, suggestions, reminding, threats and warning, offers, promises, compliments, expression of negative emotion. On the other hand, the acts threatening A positive face by $\mathrm{S}$ covers expression of disapproval, criticism, contempt, disagreement or contradiction, expression of violent emotions, irreverence, bringing bad news about A, blatant non cooperation in an activity, use of address terms and other status-marked identification in initial encounters. In accordance with the nature of FTAs proposed by Brown and Levinson, the acts chosen has an effect on negative and positive face for the speakers and the addresses. In other words, it may be 
concluded that the type of face threatened and whose face is threatened are dependent on the type of acts chosen by $\mathrm{S}$ and $\mathrm{A}$. However, the social variable of FTAs defined by Brown and Levinson (1987, p.74--83) in terms of rating the social distance, the relative powers $(\mathrm{P})$, and the absolute ranking $(\mathrm{R})$ of the imposition in a particular culture will not be discussed here since it is not the focus of sociolinguistics, i.e. to find the ratings according to social variables.

Most of scholars hold that Brown and Levinson's politeness strategies are more comprehensive than the other approaches. In this respect, the adequacy of explaining either social or psychological aspects makes the approach qualified to be the principle of analysing politeness. However, that the approach is universal engenders controversial issues. In one hand, the universality of politeness has been supported by some researchers; such as Durkheim, 1995; Tracy, 1990; Wood and Kroger 1991. They maintain that it is universal across the culture. On the other hand, their claim were rejected by some researchers who conducted study in nonewestern culture. The study reveals that it is not universal (Ide, 1989; Matsumoto, 1988; Nwoye 1992; and Pan, 1995).

\subsection{Speech Act and Communicative Action \\ Most of human actions are started} from a language use. Language is not only used to deliver messages but also to preform acts. Hence, understanding the speakers' intention demands the addresses to decipher whether they have to respond with saying or doing something. In this case, what the speakers mean is more important than what they said. The act can be performed by speakers' utterance (Yule, 1996).

The theory of speech act was proposed by Austin (1962) in 'how to do things with words.' His seminal notion was three elements of speech acts: locutionary act, illocutionary act and perlocutionary act. Expressing meaningful expression refers to locutionary act. The speakers use a number of linguistic features such grammar, vocabulary, and phonology in order to convey their intention either transactional or interpersonal communication. The second element, illocutionary act, deals with the function of speech such as compliment, request, command, promise and so on. Producing utterance may have function but also a particular effect. The logical consequence of one's utterance is called perlocutionary act or effect.

In accordance with the speech act, the main concern of enquiry was 
illocutionary act. The main features of the illocutionary act vary between authors, for example, Austin argues the difference between constative and performative as the type of illocutionary act, while Searle (1969) proposed that performative is a component of constative. This disagreement is not crucial since it is only difference in terms. The more interesting issue in speech acts is how the illocutionary act can be understood. Austin claims that Ils is conventional, while Searle (1969) believe it follows constitutive rules. Similarly, Strawson (1964) holds some of ILs covers convention instead of intention and inference.

In this respect, the addressees' inference of the speakers' utterance meaning must be based on mutuallycontext belief. According Bach and Harnish (1984), illocutionary act deals with understanding the speakers' intention. Thus understanding the speakers' intention or ILS need what Bach and Harnish called 'Mutual contextual belief' (henceforth MCB). This means in order to understand of the meaning - through inference - it can be activated by the context in which both speaker and listener has mutual beliefs or background knowledge. Furthermore, Bach and Harnish point out that MCBs consists of linguistic and communicative presumption. The former refers to mutual beliefs in a particular speech community- sharing the same values, norms among their members through language practice. Therefore, if the addressee understands the utterance the meaning of their interlocutors, they have shared background knowledge. While the latter regards with mutual understanding or communicative function among the members of a speech community. In this regard, it is impossible to bear effective communication if both the speaker and the listener have no shared background knowledge. The requirement of avoiding communication failure, MCBs, is plausible in terms of mutual understanding in communication. This principle is required for understanding sentence meaning as well as utterance meaning.

The type of speech act is related to its component. Searle (1969) classified speech acts into five types:

1) Expressiveness: deals with the expressions of feelings, such as, love, happy, etc.

2) Representatives: to state one's belief or a general truth.

3) Directives: lead someone to do something; command, order, request.

4) Commisives: to express one's commitment for future action, promise.

5) Declaratives: to change state of affairs by declaring, such as judge decision.

The differences from Austin's classification of illocutionary act is categorised into five groups: constatives, 
expositives, commissive, behabitives, and exercitives. According to Searle (1969) the classification of ILs must have principles. i.e. the categorisation must be complementary in its distribution. In this regard, he criticised Austin's classification of ILS in which there is overlapping among the classification. This is plausible since here will be unpredictable distribution among them. The other classification of illocutionary act was proposed by Bach and Harnish (1984). The classification is comprehensible and it also closely relates to Austin (1962) and Searle's (1969) classification of ILs. They classified ILs into four types and some subcategories. These subgroups are: constatives, directives, commissives, and acknowledgement. In contrast with Yule's claim that IL consists of five types. Yule's classification select expressive as one type of them in which it is subcategories of constative acts proposed by Bach and Harnis. It indicates that the current categories just chose smaller unit as a type. However, Yule's claim is by no mean lack of adequacy of explanatory principle. In this case, it is like the category based componential of higher type of ILS. The dispute on the type of ILs, it is reasonable to advocate Bach and Harnish's classification in terms of the adequacy and constraint principle.
The other issue in language use is communicative action. The success of action is raised by the addressee's respond to the validity claim by speakers. Habermas (1998) proposed universal pragmatics choosing communicative action instead of speech act. His seminal notion is three universals validity claims that can be the basic principle of speech acts:

1) A claim to the truth: deal with the truth of what is said or presupposed.

2) A claim to normative rightness: regard with the rightness of speech act in particular context or the underlying norms.

3) A claim to truthfulness of the speakers. This principle indicates universality of communicative action and derives from the speaker's perspectives. However, one problem rises whether or not the nature of speech acts proposed by Austin, Searle, Bach and Harnish are universal across the cultures. Habermas (1998) argue that universality of communicative action among the cultures and languages can be looked at by the three elements with its principle and constraints.

\section{3) Methods}

In accordance with the purposes of this paper, a qualitative method was used in analysing the gathered data. A video recording was also used to collect data about politeness and kinds of acts in Tuan 
Guru speech. This speech was a monologue by a Tuan Guru in a cemetery. The data was collected through a video recording covering politeness strategies and acts in a formal setting, especially in a religious event during a burial ceremony.

\subsection{Collecting Data}

Data was collected through a video recording taken on September 9, 2013 in a Sikur cemetery, in East Lombok. The speech duration of the Tuan Guru was 8 minutes and 19 seconds. Data was also collected through participants observation in which the observer was directly involved in this speech community in order to find the nature of politeness strategies.

\subsection{Data Analysis}

The data analysis used the qualitative method, dealing with the purposes of the study, the following procedures were used:

1) to find the nature of politeness in religious events of the Sasak community, the data was analysed based on a formal approach proposed by (Poplack, 1981), transcription, coding, translation, selection of variation or codes, and analysis.

2) to determine whether the politeness theory may be applied in demonstrating the notion of face in the Sasak community. This was analysed through categorising the type of acts used by the Tuan Guru in his speech.
3) to find the type of illocutionary acts produced by the Tuan Guru speech and examine the communicative action and its propose. The former was analysed by selection and categorisation the type of acts, while the latter was observed by categorising and determining the nature of validity claim produced by the Tuan Guru.

\section{Finding and discussion}

Based on the data, during the speech, the Tuan Guru used some acts threatening addresses' negative and positive face. The following are acts threatening hearers' negative face:

The acts chosen by speakers and addressees may threat their positive face and negative face. According to the Tuan Guru speech, there are some findings related to negative face threatening acts, but there is no finding on the positive face threatening acts. The following evidence was found in the study. Acts threatened during the speech by the Tuan Guru:

reminding:

(9) Inggih leq dunie niki endeq araq saq pasti kecuali mati

Aff-H prep N Det Neg RC Adj Prep N

'Yes, in the world nothing is sure except death.' 
suggestion:

(10) Araq kene persiapan tiang pelungguh sami, lamun endeqman siep araq masih

Psubj ADJ N $\quad$ 1ST+2ND-H

Det Conj Neg Adv ADJ

Kesempatan yaq kerisak diriq 'yaq perbaiki diri'.

$\begin{array}{lllllll}\mathrm{N} & & \mathrm{RC} & \mathrm{V} & \mathrm{RP} & \mathrm{RC} \\ \mathrm{V} & \mathrm{RP} & & & & & \end{array}$

'It is meaningful for our preparation, but if we are not ready, there is a chance to improve ourselves 'improve ourselves.'

The example above in line (9) and (10) were evidence that the acts such as, reminding and suggestion may threat negative face and threatening the addressees. However, the addresses in this case were not threatened by those acts, since it is acceptable in Sasak community and it is grounded on the Islamic principle and local wisdom. In other words, those acts did not rise real threat to the addressees or to feel any pressure by the Tuan Guru. On the other hand, such an acts are very common for people who are more educated or have legitimation by the Sasak community to remind or suggest them for goodness in their future life. Another act threatening face of addressees, that is:

request:

(7) Nunas ngelungsur keihlasan, kesabaran pelungguh sami. $\begin{array}{llll}\text { V-H } & \text { V-H } & \text { N }\end{array}$

2ND $-\mathrm{H} \quad$ Det

'Please, give me all of your sincerity and patience.'

Tiang yaq matur takziah mangkin niki, penghibur untuk keluarga saq mate khususnya

1st-H V-H N Adv-H N

Prep N RC Adj Adv

dan tiang pelungguh sami endah dan $s a q$ lain-lain $s a q$ masih hidup.

Conj $1 \mathrm{ST}+2 \mathrm{ND}-\mathrm{H}$ Det $\mathrm{Adv} \quad \mathrm{RC}$ Pron RC Adv Adj

'Right now I am going to talk about condolence as solace, especially for family of the passed away and also to all of us and the others who are still alive.'

This act by using ngiring ngelungsur in Sasak community is a highly polite request to ask others to do something. In this case, the request did not threat addressees' face, though its request took the addressees' time. In fact, there were no addressees leaving their place while Tuan Guru was giving the speech. They were devoted during the whole entire speech. It means that the Tuan Guru's utterance did not interrupt the addressees' freedom from action staying or leaving.

In addition to the politeness strategies, given the nature of politeness strategies proposed by Brown and Levinson (1987), both positive and negative 
politeness found in the speech. To minimise the threat of the addressees, the Tuan Guru used positive politeness, such as, expressing solidarity and friendship.

1) Dane-dane para almukarramun yang saya muliakan.

Mr- AF H Det you-N H CM $\mathrm{V}$

'The honourable all glorified people.'

2) Para asatiz-asatizah, para kiai, niniq, sanak, bije, laki-bini yang saya hormati.

detC You-arb N Det You-N AF-H AF-H RC Pron $\mathrm{V}$

'The respectful, all teacher, pious man, children, ladies and gentlemen.'

Besides, in line (1) and (2), in the opening of the speech he addressed the audience by using, almukarramun, assatizassatizah, dane-dane, niniq,bije, sanaq, laki-bini, to express solidarity as a group member of the Sasak people and Islamic followers. In this respect, by choosing such an act, it is used to minimize the negative face threatening of the addressee's. The Tuan Guru chose positive politeness strategies for saving the addresses' face.

Another strategy found in the study, negative politeness, was used by the Tuan Guru during his speech. He switched the code from common Sasak variety to Sasak Alus. As the example below shows:
(8) Mudah-mudahan napi saq tiang atur jari peingatan tiang pelungguh sami saq lupaq.

$\begin{array}{lcr}\text { V } & \text { RC } & \text { 1st } \text { V-H } \\ \text { prep N } & \text { 1ST+2ND-H } & \text { Det RC } \\ \text { V } & & \end{array}$

'I hope what I say for our admonition who forget.'

In accordance with the example in line (8), the Tuan Guru used the pronouns tiang (I) pelungguh (you). These pronouns have first the plural pronoun 'we' that is used in the Sasak community. In this case, by choosing the codes, the Tuan Guru juxtaposed himself with the addressees to the same level and status in terms of religion and culture. Given this choice, the addressees' negative face threatening was decreased.

To sum it up, these acts are normally chosen in case of reminding, giving advice and making a request by the Tuan Guru and it did not threat positive and negative face of the addressees. It revealed the theory of Brown and Levinson (1987) on politeness with their claim on the universality of politeness across cultures and it was not in line with findings in the Sasak language community. Based on the study, it is in line with Ide, 1989; Matsumoto, 1988; Nwoye 1992, and Pan, 1995 that politeness is not universal. On the other hand, the study revealed that positive and negative strategies were used during 
the speech. It is in line with Brown and Levinson' theory on politeness, especially positive and negative strategies to minimise the threat to both positive and negative face of the addresses.

Some types of acts used during the speech. The classification follows Bach and Harnish' (1984) approach.

\section{a. Constatives}

As a belief expression, the Tuan Guru asserted his beliefs to the audience on the truth of the future in line: 1) $\mathrm{He}$ also announced the aim of his speech and it is one subcategory of constatives, informatives. The Tuan Guru informed the audience on the purpose of his speech as in line; 2) While as in line; and 3) he use descriptives in order to describe how the next life will be like.

Assertives:

a. Lamun idup ape-ape nuq aпиq maiq, lamun mate ndeq araq maiq

conj adj pron adj

adj Neg V

tutuq riwayat wah.

adj N TM-past

'If we are alive, everything is delicious. If we are dead, nothing is delicious. Our story has already finished.'

\section{Informatives:}

(2) Tiang yaq matur takziah mangkin niki, penghibur untuk keluarga saq mate.
1st-H V-H N Adv-H N

Prep N RC Adj

Khususnya dan tiang pelungguh sami endah dan saq lain-lain saq masih hidup.

Adv Conj $1 \mathrm{ST}+2 \mathrm{ND}-\mathrm{H}$ Det Adv

RC Pron RC Adv Adj

'Right now I am going to talk about the condolence as a solace, especially for the family of the passed one and also for all of us and the others who are still alive.'

\section{Descriptives:}

(3) Selame menanti hari kiamat saq dateng, beratus-ratus tahun, berjuta tahun yaq $\begin{array}{llllll}\text { Prep V N N } & \text { RC }\end{array}$ $\mathrm{N} \quad \mathrm{RC}$

tengantih; piran yaq jelo kiamat.

Pass RC RC-F N N

'During the waiting for coming doom's-day, hundreds of years, million of years that we will wait when the doom-day will be.'

b. Directives

This is one kind of a speech act in which the speaker ask someone to do something. In this respect, the Tuan guru used requisites expressions as in line 4 to invite the audience to be grateful to Allah.

Requestives:

(4) Pertama-tama marilah kita ngiring syukur ke hadirat Allah SWT $s a q$

$$
\begin{array}{rrrr}
\mathrm{C} & & \mathrm{V} & \text { 2ND } \mathrm{V}-\mathrm{H} \\
\mathrm{N} & \text { prep } & \text { RC TM }
\end{array}
$$


wah icanin tiang pelungguh sami masih sehat, ndeq tekuburang maraq

V-H 1ST 2ND P-H Det Adv

Neg-Part Pass V Prep

almarhumah saq baruq

her-Arb P Adv

'First of all, let's give thanks to Allah who has given us health, so we are not like the dead body whom was just buried.'

\section{c. Commissives}

As a type of illocutionary acts, one subcategory was found in the Tuan Guru' speech. In line 5 , there is a swear that is used by the Tuan Guru to assert about the world and promises it is the truth.

\section{Swear That}

(5) Inggih leq dunia niki ndeq araq saq pasti kecuali mati

Aff-H prep N Det Neg RC Adj

Prep N

'Yes, in the world nothing is sure except death.'

\section{d. Acknowledgement}

As the feeling of expression, two kinds of subcategories were found: greet and bid. The former as in line 6 , the Tuan Guru greeted his audience in terms of pleasure and respect. While the latter as in line 7 he expresses his wish as to the function of his speech.
Greet:

(6) Dane-dane para almukarramun yang saya muliakan.

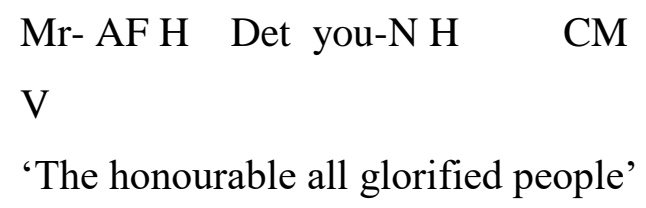

'The honourable all glorified people'

\section{Bid/wish:}

(7) Mudah-mudahan napi saq tiang atur jari peingatan tiang pelungguh sami saq lupaq.

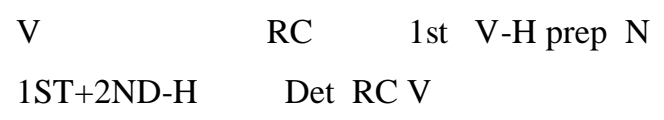

'I hope what I speak for our admonition who forgets.'

Dealing with Habermas's universal pragmatics, that is the type of communicative action reflected in the Tuan Guru's speech was in line with three validity claims. For example, as in line 3,2, 3 , the act chosen by the Tuan guru is to express the truth, truthfulness, and rightness.

\section{Conclusion}

The study examined the nature of speech behaviour in terms of politeness and language use in context with scrutinising the Tuan Guru speech in the Sasak community. However, the data was only collected by a video recording for 8 minutes 19 seconds involving only one Tuan Guru as the participant. In addition to the type of illocutionary acts found in the examined Tuan Guru speech, it is closely 
related to the types of Searle, Bach and Harnish's classification. There were four types of ILs found: constatives, directives, commissives, and acknowledgement. In other words, only declarative was not found. However, the nature of expression, especially, greeting as one subcategory of acknowledgement, is not only used by speaker to express pleasure of meeting the audience's, but a respectful norm or politeness of expression. Furthermore, the universal pragmatic as proposed by Habermas can be underpinned by the finding on the nature of claim to be the truth, speaker rightness, truthfulness in the Tuan Guru's speech.

Finally, there is a need for further research on this topic with more participants and data collection techniques. For further study, it is important to find more subcategories of each acts by collecting data in formal and informal context. It is for revealing on the nature of speech act and patterns of communication performed in relation to politeness and norms.

\section{References}

Austin, J.L. (1962). How To Do Things with Words. Cambridge: Harvard University Press.

Bach, K., \& Harnish, R. (1984). linguistic Communication and Speech Acts. Cambridge: MIT Press.
Brown, P., and Levinson, S. C. (1987). Politeness. Some universals in Language Use. Cambridge: Cambridge University Press.

Durkheim, E. (1995). The Elementary Forms Religious Life (New Eds). New York: Free Press.

Ide, S. (1989). Formal Forms and Discernment: Two Neglected Aspects of Universals of Linguistics Politeness. Multilingua, 8, 223--248.

Goffman, E. (1967). Interaction Ritual: Essays on Face to Face Behaviour. Garden city, New York: Anchor Books.

Grice, H. P. (1975). Logic and Conversation. In P. Cole \& J. Morgan (Eds), Syntax and Semantic 3, Speech acts (pp. 41--58). New York: Academic Press.

Lakoff, R. (1973). The Logic of Politeness or Minding p's and q's.Chicago Linguistic Society, 8: 292--305.

Leech, G. N. (1983). Principles of Pragmatics. London \& New York: Longman.

Matsumoto, Y. (1988). Re-examination of The Universality of Face: Politeness Phenomena in Japanese.Journal of Pragmatics, 12, 403--426.

Nwoye, O. G. (1992). Linguistic Politeness and Socio-Cultural Variations of The Notion of Face.Journal of Pragmatics, 18, 309--328.

Pan, Y. (1995). Power Behind Linguistic Behaviour: Analysis of Politeness Phenomena in Chinese Official Settings. Journal of language and social psychology. 
Searle, J. (1969). Speech acts. Cambridge, England: Cambridge University Press.

Wood, L. A. and Kroger, R.O. (1991). Politeness and Forms of Address. Journal of Language and Social Psychology, 10, 145--168.

Watts, R. J. (2003). Politeness: Key Topics in Sociolinguistics. Cambridge: Cambridge University Press. 
18 | Mabasan, Vol. 11 No.1, Januari--Juni 2017:1--16 